\title{
TURCY I IMPERIUM OSMAŃSKIE W PROROCTWACH POŁUDNIOWOSŁOWIAŃSKICH
}

\author{
PAWEŁ DZIADUL
}

\begin{abstract}
Paweł Dziadul, Turcy i Imperium Osmańskie w proroctwach południowosłowiańskich (The Turks and the Ottoman Empire in South Slavonic prophecies).

The article presents anti-Turkish and anti-Islamic ideas found in South Slavonic prophecies. The Orthodox Slavs in the Ottoman period actualized old apocalyptic material and created new prophecies using marginal glosses, interpolations or compilations. Anti-Turkish and anti-Islamic ideas focused mainly on the future Ottoman doom and the image of the legendary emperor who was supposed to defeat the "Ishmaelites".
\end{abstract}

SŁOWA KLUCZOWE: Imperium Osmańskie, idee antyislamskie, proroctwo, Turcy, Słowianie południowi KEYWORDS: Ottoman Empire, anti-Islamic ideas, prophecy, the Turks, the South Slavs

Balcanica Posnaniensia. Acta et studia, XXI, Poznań 2014, Wydawnictwo Instytutu Historii UAM, pp. 25-36, ISBN 978-83-63047-59-7, ISSN 0239-4278. Polish text with a summary in English.

Paweł Dziadul, Uniwersytet im. A. Mickiewicza w Poznaniu, Instytut Filologii Słowiańskiej, ul. Fredry 10, 61-701, Poznań, Polska - Poland, pawe190883@gmail.com.

Podboje Turków osmańskich w XIV-XV w. oraz dostanie się prawosławnych chrześcijan pod całkowicie obcy system konfesyjno-kulturowy pax Ottomana ${ }^{1}$ musiały zyskać odpowiednie symboliczne uzasadnienie oraz teologiczną konceptualizację dziejową zgodnie z obowiązującym wówczas modelem świata. Nowy dezintegracyjny element $\mathrm{w}$ postaci obcego najazdu i zetknięcie się z odmienną orientalną kulturą konotowały konieczność reinterpretacji oraz modyfikacji istniejącego już materiału prorockiego wraz z wbudowanym weń systemem topicznym, który dostarczał specyficzny klucz umożliwiający odkodowanie sensu dziejów. Bizantyńskosłowiańska tradycja apokaliptyczna i prorocka dojrzewała na teologiczno-ideowej matrycy ukształtowanej nie tylko przez piśmiennictwo biblijno-patrystyczne, lecz również przez specyficzne teksty-modele, w dużej mierze o apokryficznych proweniencjach, takie jak choćby: Objawienie Pseudo-Metodego Patarskiego, apokryficzne Wizje Daniela (np. słowiańska Wizja Daniela, Ostatnia Wizja Daniela), proroctwa Leona Mędrca (chresmoi), Żywot Andrzeja Jurodiwego (ściślej część tzw. Apokalipsa Andrzeja Jurodiwego) czy apokryficzna Apokalipsa św. Jana Teologa (Pytania

\footnotetext{
${ }^{1}$ Zob. A. Toynbee, Studium historii, przeł. J. Marzęcki, Warszawa 2000, s. 128, 167, 370.
} 
św. Jana Teologa na Górze Tabor). Wyekscerpowane z nich toposy uformowały sieć symboliczno-pojęciową, ułatwiającą egzegezę otaczającej rzeczywistości i stały się częścią uniwersum symbolicznego, które nadawało sakralny porządek historii, wiążąc przeszłość, teraźniejszość i przyszłość ${ }^{2}$. Materiał prorocki budował układ odniesienia dla aktualnych wydarzeń historycznych poprzez wskazywanie ich znaczenia dla zbawczej przyszłości.

Najazdy Turków osmańskich stały się jednym z głównych generatorów nagłego wybuchu nastrojów eschatologicznych w XV w., które podsycała również obawa przed rokiem 7000 „od stworzenia świata” według rachuby bizantyńskiej (=1491/1492 r.) $)^{3}$. Konceptualizację elementu destabilizującego ułatwiał fakt, iż wpisywał się on w gotowy, ukształtowany na bizantyńskim podłożu kulturowym wzorzec topiczny, który był jednocześnie uniwersalny i historyczny, dlatego nigdy nie tracił swej aktualności w obliczu niestabilnego procesu dziejowego. To głównie powstały w VII w., w dobie arabskich podbojów na Bliskim Wschodzie, utwór Pseudo-Metodego ${ }^{4}$ wykreował szereg charakterystycznych toposów, rozbudowywanych przez powstające $\mathrm{w}$ kolejnych wiekach inne pisma prorockie. Pseudo-Metody wieszczył, że jednym z prodromów końca świata u schyłku siódmego tysiąclecia „od Adama” (rako

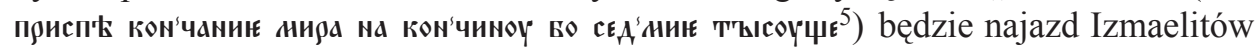

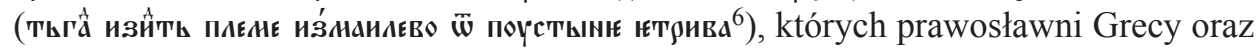
Słowianie zaczęli utożsamiać z Turkami, wiązanymi w ten sposób z potomkami kazirodczego związku Hagar i Izmaela (Rdz 16, 1-16). Prócz terminu „Izmaelici” używano również pokrewnych formuł, takich jak „Hagaryci”, „synowie Izmaela” lub „synowie Hagar”, akcentując najczęściej ich barbarzyński, dziki i nieokiełznany charakter (nazywani bezbożnymi, nieprawymi, przeklętymi etc.), co ewokowało koncepcję zderzenia dwóch światów, dwóch cywilizacji, jednej nomadycznej, wojowniczej, kierującej się zasadami świętego dżihadu oraz drugiej dojrzałej, osiadłej cywilizacji starych kultur bałkańskich. Nawiązania biblijne potęgują negatywny sposób obrazowania obcych najeźdźców, porównywanych do smoka (por. Ap 12, 3-4), pomiotu żmii i skorpiona (por. Pwt 8, 15; Ez 2, 6; Łk 10, 19; Ap 9,5; Ap 12, 3-4)7,

${ }^{2}$ P.L. Berger, T. Luckmann, Społeczne tworzenie rzeczywistości. Traktat z socjologii wiedzy, przeł. J. Niżnik, Warszawa 2010, s. 151.

${ }^{3}$ Zob. P. Dziadul, An Overview of Eschatological Moods Among the Orthodox Slavs During the 14th and 15th Centuries, „Die Welt der Slaven”, 2012, Jg. 57, Heft 2, s. 278-292; P. Dziadul, W oczekiwaniu na Paruzję. Myśl eschatologiczna w prawosławnym piśmiennictwie stowiańskim do połowy XVI wieku, Kraków 2014, s. 153-176.

${ }^{4}$ Zob. P. Alexander, The Byzantine Apocalyptic Tradition, Berkeley-Los Angeles-London 1982, p. 13-33.

${ }^{5}$ Слово Мефодия Патарского о изарствии язык последних времен, в: Апокрифические тексты, сост. П.А. Лавров, Сборник отделения русского языка и словесности, т. LXVII, Санкт- Петербург 1899, c. 15.

${ }^{6}$ Ibidem, c. 15.

${ }^{7}$ Zob. Napis na stupie kosowskim, w: Dar słowa. Ze starej literatury serbskiej, przeł. T. Wątor-Naumow, A.E. Naumow, W. Kotwiczowa, wyb. A.E. Naumow, Łódź 1983, s. 130; Jefimija, Pochwała księciu Lazarowi, w: Dar stowa..., s. 139. 
Goliata (por. $1 \mathrm{Sm} \mathrm{17)})^{8}$. Zarówno w dawnych proroctwach, jak i w pismach wielu autorów południowosłowiańskich z tego okresu (m.in. Isaija Serski, Dymitr Kantakuzen, Konstantyn Kostenecki) turecki najazd, otwierający czas, kiedy „żywi zazdrościli umarłym śmierci” (por. Koh 4, 2; Ap 14, 13) ${ }^{9}$, był zgodny z wyrokami Bożej Opatrzności, karzącej grzesznych chrześcijan (por. Pwt 9, 4-6), dlatego topos „kary za grzechy" funkcjonował jako immanentny element egzegetyczny.

Okres panowania osmańskiego naznaczonego prześladowaniami, rzeziami i wielkim uciskiem chrześcijan pozostaje jednak swoistym mitem ukonstytuowanym przez krystalizujące się głównie w XIX w. mitologie narodów bałkańskich, usiłujących wymazać najdrobniejsze ślady tureckiej przeszłości. Imperium Osmańskie odznaczało się niewątpliwie większą tolerancją niż wiele krajów Zachodu w tym okresie. Jednak tolerancja nie oznaczała równości, bowiem chrześcijanie byli objęci specyficznymi prawami restrykcyjnymi (np. zakaz jazdy konno, noszenia broni, budowy i remontu cerkwi bez pozwolenia). Ponadto znajdowali się w specjalnym systemie podatkowym (np. podatek pogłówny - cizye) oraz obowiązywał ich tzw. devşirme (,danina krwi”") ${ }^{10}$. Zgodnie z muzułmańską wizją świata ziemie i ludy znajdujące się poza władzą islamu (dar al-harb) podlegały prawom dżihadu, jednak celem Turków nie było ich unicestwienie, lecz podbój oraz dominacja z korzyścią dla islamu. Podbite ludy (dhimmi) innego wyznania (chodzi tu nie o pogan, których według Koranu należy nawracać lub zwalczać, lecz o ahl al-kitâb, czyli „ludy księgi”11) były dość łaskawie traktowane i otrzymywały odpowiednie miejsce w hierarchii ${ }^{12}$. Kościół prawosławny uzyskał od władzy osmańskiej szeroką autonomię, jednak patriarcha uzależniony był od podmiotu władzy związanego z obcą kulturą, od wydawanych przez sułtanów beratów, dlatego będąca podstawą bytu polityczno-religijnego idea diarchii w okresie osmańskim musiała ulec deprecjacji. Państwo osmańskie generalnie nie ingerowało w życie codzienne ani wierzenia ludności chrześcijańskiej ${ }^{13}$. Muzułmanie nie funkcjonowali w powszechnej świadomości podbitych chrześcijan prawosławnych jako zagrożenie ideologiczne czy doktrynalne, przynajmniej nie w takim stopniu jak Kościół katolicki (szczególnie w dobie kontrreformacji). Turków i samo Imperium Osmańskie postrzegano w nieco innym wymiarze, m.in. historiozoficznym, który

${ }^{8}$ Anonim z Ravanicy, Stużba świętemu Lazarowi, w: Dar słowa..., s. 149.

${ }^{9} \mathrm{Nr}$ 4944, Стари српски записи и натписи, књ. III, сред. Љ. Стојановић, Београд 1902, c. 43; por. Ефрем Сирин, Слово на пришествие Господне, на скончание мира и на пришествие Антихристово, в: idem, Избранные творения, изд. Сретенского монастыря, Москва 2007, с. 258.

10 Zob. L. Stavrianos, The Balkans since 1453, New York 2000, p. 105; P. Sugar, Southeastern Europe under Ottoman Rule 1354-1804, Seattle-London 1977, p. 31-59.

11 „Walczcie z tymi spośród Ludu Księgi, którzy nie wierzą w Allaha, ani w Dzień Ostatni, ani nie uważają za nieprawe tego, co Allach i Jego Posłaniec ogłosili nieprawym, aż do czasu, gdy zapłaca należność, uznając to za łaskę i uznają swe podporządkowanie" (Koran 9: 29), zob. Święty Koran, tekst arabski i thumaczenie polskie, Tilford 1990.

${ }^{12}$ H. Inalcik, Imperium Osmańskie: epoka klasyczna 1300-1600, przeł. J. Hunia, Kraków 2006, s. 51.

${ }^{13}$ B. Jelavich, Historia Bałkanów - wiek XVIII i XIX, t. 1, przeł. J. Polak, K. Salawa, Kraków 2005, s. 60-61. 
egzemplifikują idee, toposy, symbole pojawiające się w piśmiennictwie prorockim $\mathrm{z}$ tego okresu.

W okresie postbizantyńskim wśród Greków popularnością od drugiej połowy XVI w. zaczęła cieszyć się Apokalipsa św. Jana, która wcześniej, pomimo uznania jej kanoniczności w VI-VII w., nie wzbudzała większego zainteresowania na gruncie teologicznym czy liturgicznym. Na wzrost popularności księgi wpłynęła myśl zachodnia, przede wszystkim protestancka, co wynikało z intensyfikacji kontaktów interkulturowych między protestantami a prawosławnymi w rzeczywistości potrydenckiej. Mająca antykatolicki i antyislamski charakter literatura egzegetyczna objaśniająca Apokalipsę (interesowano się szczególnie zagadkową liczbą bestii 666, wiązaną z końcem panowania islamu i odrodzeniem Bizancjum; zajmowano się też tematem personifikacji Antychrysta, utożsamianego z papieżem lub Mahometem) ${ }^{14}$ stanowi dużą część postbizantyńskiej literatury eschatologicznej, wyznaczając nowy etap rozwoju teologii prawosławnej (np. komentarze Maksimosa Kallipolitisa, Zachariosa Gerganosa, Christophorosa Anghelosa, Georgiosa Koressiosa, Anastasiosa Gordiosa i innych) ${ }^{15}$. Dawne proroctwa reinterpretowano przede wszystkim poprzez wprowadzanie nowych wątków związanych z przyszłym upadkiem państwa osmańskiego, odrodzeniem prawosławia, Cesarstwa Bizantyńskiego oraz wyzwoleniem Konstantynopola przez ,płowowłosy ród” (topos , jasnowłosych” / ,jasnobrodych” - роүсын врадыи był często wykorzystywany w bizantyńsko-słowiańskiej literaturze apokaliptycznej i prorockiej, gdzie identyfikowano go raczej z mieszkańcami łacińskiego Zachodu, szczególnie w dobie IV krucjaty). Od XVI w. zaczęto wierzyć, że ta prorocza formuła dotyczy przyszłych wyzwolicieli miasta Konstantyna - Rosjan ${ }^{16}$, o czym przekonywała np. tajemnicza interpretacja inskrypcji Leona Mędrca z grobowca Konstantyna Wielkiego przypisywana patriarsze Giennadiuszowi Scholariosowi ${ }^{17}$.

Południowosłowiańska literatura prorocka od XVI w. rozwijała się na dwóch głównych płaszczyznach. Z jednej strony, kopiowano dawne proroctwa (m.in. Objawienie Pseudo-Metodego, apokryficzne Wizje Daniela, chresmoi Leona Mędrca), a $\mathrm{z}$ drugiej, powstawały nowe pisma ${ }^{18}$. Jednak wbrew pozorom nowych utworów antytureckich o charakterze prorockim czy apokaliptycznym od XVI w. zachowało się niewiele. Przerabiano przede wszystkim stary materiał poprzez kompilacje, glo-

${ }^{14}$ R. Lozanova, Apocalyptic Ideas after the Fall of the Byzantine Empire. Word and Image, в: Средновековна християнска Европа: Изток и Запад - иенности, традиции, общувание, под ред. на В. Гюзелев, А. Милтенова, София 2002, с. 309.

15 Zob. A. Argyriou, Les exégèses grecques de l'Apocalypse à l'époque turque (1453-1821). Escuisse d'une histoire des courants idèologiques au sein du people grec asservi, Thessalonique 1982.

${ }^{16} \mathrm{~W}$ niektórych starszych odpisach Opowieści o zdobyciu Carogrodu Nestora Iskandera (odpis z Chronografu roku 1512 czy odpis z Latopisu Waskriesienskiego) termin „,русий род” został zastąpiony terminem ,„руский род”, История о взятии Царьграда турками Нестора Искандера, „Труды отдела древнерусской литературы", 1954, т. 10, с. 177.

17 Zob. C. J. Turner, An Oracular Interpretation attributed to Gennadius Scholarius, „Hellenika”, 1968,21, p. $40-47$.

18 V. Tapkova-Zaimova, A. Miltenova, Historical and Apocalyptic Literature in Byzantium and Medieval Bulgaria, Sofia 2011, p. 547-564. 
sy $\mathrm{i}$ interpolacje. Materiał ten kopiowano oraz grupowano w większe cykle (w kodeksach typu miscellanea ${ }^{19}$ ), dlatego w tym przypadku możemy mówić o ciągłości bizantyńsko-słowiańskiej tradycji prorockiej i apokaliptycznej (proces cyrkulacji materiału prorockiego na gruncie południowosłowiańskim trwał aż do XIX w., do rosyjsko-tureckiej wojny $1877-1878^{20}$ ). Za przykład modyfikacji dawnego materiału w okresie osmańskim może posłużyć XV-wieczne serbskie proroctwo Leona Mędrca, przypisywane w XVII i XVIII-wiecznych rękopisach despocie Stefanowi Lazareviciowi. W jednym XVIII-wiecznym manuskrypcie (z monastyru Hopovo) utwór uzupełniono charakterystycznymi glosami marginalnymi, precyzującymi sens pewnych zagadkowych symboli w duchu antytureckim. Pojawiającą się w proroctwie tajemniczą kobietę i symbol konia utożsamiono z rodem tureckim, a jastrzębia, symbolizującego triumf i zmartwychwstanie, z Moskwą, w której widziano przyszłego wyzwoliciela

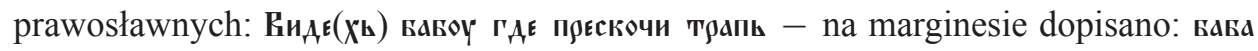

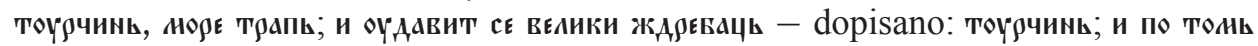

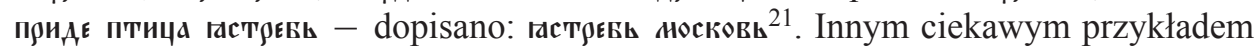
reinterpretacji materiału prorockiego jest pochodzący z XVII-wiecznego manuskryptu (Biblioteka Narodowa im. św. Cyryla i Metodego w Sofii, nr 1051) utwór (Gлово

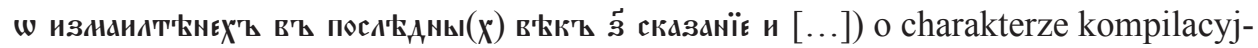
nym, oparty przede wszystkim na Objawieniu Pseudo-Metodego. Pierwsza część pisma, będąca skondensowaną przeróbką utworu Pseudo-Metodego, dotyczy nadejścia Izmaelitów w „siódmym wieku” (tysiącleciu) dziejów świata, a druga ukazuje przybycie Antychrysta. Autor mówiąc o upadku Gallipoli w 1359 r. i Konstantynopola w 1453 r. (co być może wskazuje na drugą połowę XV w. jako czas powstania utworu) obrazuje dziki oraz barbarzyński charakter Izmaelitów, wiążąc ich literalnie i figuralnie z pustynią, ewokującą brak wiary, bezbożność (п४стиню ндјичєть БєзьБж(c)TBo) ${ }^{22}$.

Po tureckim podboju Bałkanów niektóre tradycyjne idee eschatologiczne zaczęto łączyć już nie tylko z apokaliptycznym najazdem Izmaelitów, ale od XVI w. w ogóle z Imperium Osmańskim. Specyficzne przeniesienie pewnych koncepcji na państwo osmańskie ułatwiał fakt, iż to ono zajęło miejsce Cesarstwa Wschodniorzymskiego (Bizancjum), które sytuowało się często w centrum zainteresowania rozmaitych proroctw. Zgodnie z teorią następstwa ziemskich monarchii (por. Dn 2; Dn 7), wyznaczającej specyficzny model periodyzacji dziejów, Bizancjum odbierane było (w bizantyńskich komentarzach do Księgi Daniela) jako ostatnia monarchia z czterech bądź jako „mesjańskie królestwo” funkcjonujące poza łańcuchem imperiów ziem-
19 Ibidem, p. 49.
20 Ibidem, p. 550.
21 Đ. Daničić, Proroštvo despota Stefana Lazarevića, „Starine”, 1872, 4, s. 84; V. Tapkova-Zaimova, A. Miltenova, op. cit., p. 456.

22 Tekst, zob. А. Милтенова, Новооткрито българско историко-апокалиптично съчинение, отразяващо историческите събития през XIV-XV век, в: Българско средновековие: общество, власт, история. Сборник в чест на проф. д-р. Милияна Каймакамова, съст. Г. Николов, А. Николов, София 2013, c. $112-129$. 
skich. Jednak po upadku Bizancjum należało zmodyfikować tradycyjne idee eschatologiczne przenosząc je na Imperium Osmańskie, które mogło wówczas stać się ostatnią monarchią doczesną, ewentualnie „królestwem Antychrysta”. Niektórzy zaczęli wierzyć bowiem, że upadek Konstantynopola w 1453 r. nie był prodromem końca świata, lecz początkiem panowania ,syna zatracenia” (2 Tes 2, 3-4) na Ziemi, po którym nastąpi triumf prawosławia ${ }^{23}$. Powstające od XVI w. prorockie utwory o charakterze antytureckim koncentrowały się przede wszystkim na wizji przyszłego upadku Imperium Osmańskiego i na postaci cesarza „końca czasów”, z którym zaczęto wiązać nadzieję na wyzwolenie. Idee te pojawiały się m.in. w zmodyfikowanych proroctwach Leona Mędrca (chresmoi), które ciesząc się nową popularnością od XVI w., krążyły za pośrednictwem weneckich kupców oraz dyplomatów zarówno na chrześcijańskim Wschodzie, jak i Zachodzie. Miejsce centralne w tych proroctwach zaczęło zajmować Imperium Osmańskie i sułtani, na których przenoszono topiczne wzorce bizantyńskiej apokaliptyki (sułtani wtłaczani byli w ramy charakterystycznej sekwencji cesarzy, których rządy poprzedzać miały odnowę „królestwa chrześcijan” i koniec świata). Wśród licznych XVI-wiecznych ilustrowanych kolekcji pism prorockich sygnowanych imieniem Leona Mędrca warto wymienić powstały na Krecie zbiór autorstwa Francesca Barozzi'ego z 1577 r. (obecnie w Oksfordzie, Barocc. gr. 170) czy ten najpopularniejszy, zobrazowany niezwykłymi miniaturami przez kreteńskiego artystę Georgiosa Klontzasa ${ }^{24}$. Towarzyszace prorockim wersom ilustracje (np. w XVI-wiecznym rękopisie z Biblioteki Marciana w Wenecji; gr. VII, 22) obrazowały przewidywaną kolejność zdarzeń, od izmaelickich sukcesów (na jednej ukazującej zajęcie przez Turków „,siedmiowierchego" miasta Konstantyna miniaturze Mehmed II otrzymuje od Chrystusa symboliczne zwycięstwo) do ich przepędzenia z Carogrodu przez legendarnego cesarza „końca czasów”25.

Wenecja (będąca od końca XV w. istotnym ośrodkiem serbskiego drukarstwa cyrylickiego) odegrała w okresie postbizantyńskim kluczową rolę w łączeniu tradycji prorockiej i apokaliptycznej chrześcijańskiego Wschodu i Zachodu oraz w zachowaniu jej ciągłości. Być może za weneckim pośrednictwem nowe antytureckie proroctwa trafiały na ziemie serbskie od końca XV w. Interesującym przykładem pism nowego typu (z kolekcji ilustrowanych) są tzw. ,proroctwa św. Sawy”, pochodzące z niezachowanego do naszych czasów manuskryptu, o którego istnieniu dowiadujemy się z relacji habsburskiego sekretarza i wysłannika Corneliusa Dupliciusa de Scheppere, nocującego 11-12 sierpnia 1533 r. w, mającym bliskie związki z Wenecja, monastyrze Mileševa, gdzie przechowywano relikwie św. Sawy. Narracja ta unaocznia pewne XVI-wieczne koncepcje dotyczące przyszłej klęski oraz upadku państwa osmańskiego. Scheppere twierdził, że w monastyrze znajdują się tajemnicze proroc-

\footnotetext{
${ }^{23}$ R. Lozanova, op. cit., s. 307.

${ }^{24}$ C. Mango, The Legend of Leo the Wise, „Зборник радова византинолошког института”, 1960, књ. 6, с. 78-81.

${ }^{25}$ Zob. C. Марјановић-Душанић, Псеудо-Методијев спис и реактуализачија пророчких текстова у Срба крајем средњег века, у: Византијски свет на Балкану, књ. 2, ур. Б. Крсмановић, Љ. Максимовић, Р. Радић, Београд 2012, с. 630-631.
} 
twa, które tamtejsi mnisi przypisują św. Sawie. Z relacji dowiadujemy się również o zagadkowych miniaturach, którymi opatrzone były pisma. Znajdowały się na nich rozmaite symbole (m.in. lis, orzeł, ukoronowany lew, rycerze, statek i siedzący na nim cesarz oraz inne), których zachodni wysłannik nie rozumiał. Na głównym rysunku widniało miasto o siedmiu wieżach oraz żelaznej bramie, utożsamiane przez Serbów i Bułgarów, jak twierdzi Scheppere, z Carogrodem. Św. Sawa rzekomo wieszczył mu rychły upadek w okresie jego największej świetności. Serbscy mnisi nie chcieli pokazać proroctw współtowarzyszowi podróży Scheppere’a Muhammedowi, myśląc że jest on Turkiem ${ }^{26}$. Opis habsburskiego wysłannika wskazuje, że „proroctwa św. Sawy" były najprawdopodobniej przeróbką przepowiedni Leona Mędrca (chresmoi), które również opatrywano często enigmatycznymi ilustracjami. Tradycyjnie jednym z prodromów końca świat, według proroctw Leona Mędrca (również według Żywota Andrzeja Jurodiwego, niektórych apokryficznych Wizji Daniela) miał być upadek „siedmiowierchego" miasta Konstantyna. Skoro jego klęska w $1453 \mathrm{r}$. przed zbliżającym się końcem siódmego tysiąclecia (1491/1492 r.) nie zakończyła się żadną katastrofą, należało zmodyfikować tradycyjne koncepcje eschatologiczne w kontekście nowej sytuacji historyczno-politycznej. W obawie przed represjami prawosławni zmuszeni byli kamuflować swoje antytureckie i antyislamskie manifesty, czego dowodem mogą być właśnie ,proroctwa św. Sawy”, w których przepowiednia o upadku Carogrodu konotowała wiarę w koniec Imperium Osmańskiego oraz wyzwolenie Bałkanów. Interesującym przykładem specyficznego literackiego kamuflażu są kryptogramy, których używano w pewnych formułach określających Turków, takich jak np. „Izmaelici” lub „Hagaryci” (Teodor Ljubavić w swym drukowanym psał-

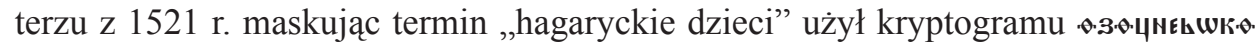
odsyłającego do przedziałów liczbowych i literowego zapisu cyfr cyrylickich ${ }^{27}$ ).

Ideę końca państwa osmańskiego miały wyrażać różnego typu spekulacje dotyczące dat, wydarzeń, postaci czy ich imion. Zintensyfikowały się one szczególnie pod koniec XVI w., bowiem w roku 1591/1592 upływało muzułmańskie millenium (tysiąc lat od Hidżry liczonej według systemu muzułmańskiego Anno Hegirae), co dało impuls do rozwoju różnych nastrojów apokaliptycznych i mesjanistycznych wśród samych Turków i islamskich konwertytów ${ }^{28}$. Końca Imperium (konotującego wyzwolenie przez chrześcijan Carogrodu) oczekiwano zwłaszcza podczas panowania Mehme-

${ }^{26}$ P. Matković, Putovanja po Balkanskom poluotoku XVI vieka. Putovanje Kornelija Duplicia Šepera g. 1533, „Rad JAZU”, 1882, 62, s. 60-61; J. Novaković-Lopušina, Putopisi flamanskih diplomata 16. veka, „Erazmo. Godišnjak za holandsku i flamansku književnost”, 1995/1996, br. 4., s. 113; С. Ћирковић, Пророчанства светога Саве, „Прилози за књижевност, језик, историју и фолклор”, 2001, књ. 67, с. 5-10.

${ }^{27} \mathrm{Nr} 5890$, Стари српски записи и натписи, књ. III..., с. 151. Użycie kryptogramów tego typu polegało na substytuowaniu jednych liter innymi, np. literę $\bullet$ należy zastapić $\mathbf{A l}(\boldsymbol{\theta} \cdot=9$, czyli przedział licz-

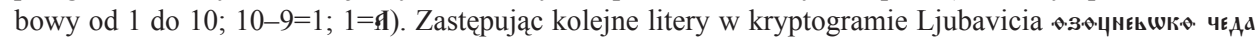
otrzymamy zwrot агарєньска чєда (,,hagaryckie dzieci”).

${ }^{28}$ Zob. T. Krstić, Contested Conversions to Islam. Narratives of Religious Change in the Early Modern Ottoman Empire, Stanford 2011, p. 75-97. 
da III (1595-1603), gdyż nosił on to samo imię, co zdobywca Carogrodu Mehmed II ${ }^{29}$. Proroctwa tego typu konstruowano poprzez analogię (dotyczyła ona również imion ojców sułtanów - Murad i matek cesarzy - Helena) do wcześniejszych bizantyńskich czy postbizantyńskich przepowiedni, wieszczących, iż założone przez cesarza imieniem Konstantyn (Konstantyn Wielki) miasto upadnie w czasie rządów władcy noszącego to samo imię (Konstantyn XI) ${ }^{30}$. Różnego typu proroctwa o końcu Imperium Osmańskiego krążyły zarówno na Wschodzie, jak i na Zachodzie. Rychły upadek państwa osmańskiego ogłaszał m.in. Paisius Ligarides (jego Chesmologion przełożył dla dworu rosyjskiego mołdawski autor Nicolae Milescu Spătarul) $)^{31}$, Pseudo-Sphrantzes (Chronicon Maius) czy wielki dragoman Porty - Panagiotis Nikousios ${ }^{32}$. Tego typu idee propagowali również m.in. dominikanin Giovanni Nanni da Viterbo ${ }^{33}$, Fransesco da Meleto z Florencji ${ }^{34}$ czy Johann Singriener, który wydał pismo De eversione Europae prognosticon (przypisywane lekarzowi i astrologowi Antoniemu Torquato) ${ }^{35}$. Dużą rolę w rozpowszechnianiu idei antytureckich w Europie odegrały też polskie turcyki (tworzone m.in. przez Stanisława Orzechowskiego, Józefa Wereszczyńskiego, Krzysztofa Warszewickiego, Wawrzyńca Chlebowskiego) ${ }^{36}$. Jednym z najpopularniejszych krążących na Zachodzie XVI-wiecznych utworów wieszczących upadek państwa osmańskiego, triumf chrześcijan nad islamem i przepędzenie Turków z Bałkanów oraz dawnych posiadłości bizantyńskich było mające korzenie tureckie proroctwo o „czerwonym jabłku” (kizll elma; symbolizującym panowanie nad światem), z którym zapoznał Europę chorwacki arystokrata - Bartholomeus Georgievicz (Bartolomej Đurđević) w Vaticinium infidelium lingua turcica ${ }^{37}$.

Proroctwa o upadku państwa osmańskiego rozwijały się na gruncie południowosłowiańskim do drugiej połowy XIX w. ${ }^{38}$. Wśród Serbów tego typu przepowiednie

${ }^{29}$ R.G. Păun, Enemies Within: Networks of Influence and the Military Revolts against the Ottoman Power (Moldavia and Wallachia, Sixteenth-Seventeenth Centuries), in: The European Tributary States of the Ottoman Empire in the Sixteenth and Seventeenth Centuries, eds. G. Kármán, L. Kunčević, Leiden 2013, p. 236.

${ }^{30} \mathrm{~Np}$. Nestor Iskander w Opowieści o upadku Carogrodu wołał: „Костянтином създася и паки Костянтином и скончася", Повесть о взятии Царьграда турками в 1453 году, в: Библиотека литературы древней Руси - вторая половина XV века, т. 7, под ред. Д.С. Лихачева, Л.А. Дмитриева, А.А. Алексеева, Н.В. Понырко, Санкт-Петербург 2005, с. 64.

${ }^{31}$ Zob. A. Argyriou, op. cit., p. 111-112; C. Mango, op. cit., s. 86-87.

${ }^{32}$ Panagiotis Nikousios posiadał przynajmniej jedną antologię bizantyńskich i postbizantyńskich proroctw, które dał w prezencie wołoskiemu historykowi i arystokracie Konstantynowi Kantakuzenowi, propagującemu idee antytureckie i antyislamskie, zob. R. G. Păun, op. cit., p. 238.

33 K.M. Setton, Western Hostility to Islam and Prophecies of Turkish Doom, Philadelphia 1992, p. 18.

${ }^{34}$ Ibidem, p. 22.

${ }^{35}$ Ibidem, p. 25-26; zob. też: J. Deny, Les pseudo-prophéties concernant les Turcs au XVIe siècle, „Revue des Études Islamiques”, 1936, 10, p. 207-216.

${ }^{36}$ Zob. J. Nosowski, Polska literatura polemiczno-antyislamistyczna XVI, XVII, XVIII w.: wybór tekstów i komentarze, z. 1-2, Warszawa 1974.

${ }^{37}$ K.M. Setton, op. cit., p. 29-46; J. Deny, op. cit., p. 217-220.

38 Zob. Б. Ангелов, Три исторически разказа. Съчинения за падането на Туриия, „Известия на Института за история”, 1964, 14/15, с. 486-494; В. Мутафчиева, „Предсказанията” за края на ос- 
szczególną popularnością zaczęły cieszyć się w drugiej połowie XVII i w XVIII w., kiedy wojny rosyjsko-tureckie i austriacko-tureckie stymulowały nadzieje na przyszłe wyzwolenie. W połowie XVIII w. karłowicki metropolita Pavle Nenadović informował austriacki dwór o pochodzących z różnych proroctw znakach, zapowiadających turecką klęskę ${ }^{39}$. Z końca XVII w. zachował się również ciekawy zapis Atanasija Daskala Srbina o pewnym mnichu z monastyru Ravanica - Ananiju, który zapytany przez tureckiego dostojnika o los Imperium Osmańskiego, odpowiada, że według „ksiag chrześcijańskich” zostanie ono zniszczone i upadnie. Dowiadujemy się ponadto ze słów Turka, że sam prorok Mahomet na łożu śmierci wypowiedział rzekomo proroczą tezę, głosząca, iż po upływie tysiąca dziewięćdziesięciu lat (według ery muzułmańskiej) od jego odejścia cały ród turecki wyginie ${ }^{40}$. W innym opisującym spustoszenie ziemi serbskiej fragmencie Atanasije Daskal Srbin mówi o znaku na niebie - komecie w roku 7191 (=1682/83), która, jak wieszczył rzekomo ,pradawny filozof”, zwiastuje ,przemianę carstwa”, tzn. koniec Imperium Osmańskiego ${ }^{41}$. Z kolei, w XVIII-wiecznym Kodeksie metropolity Mihaila (będącym wariantywną formą serbskich chronografów), w końcowej części Opowieści o zajęciu Carogrodu przez bezbożnych Izmaelitów odnajdujemy fragment o tajemniczym świętym ogniu na Grobie Pańskim w Jerozolimie i niezwykłą prośbę-modlitwę. Wyrażona została tu idea jedności ujarzmionych chrześcijan prawosławnych i zniewolonych carstw (влагоч

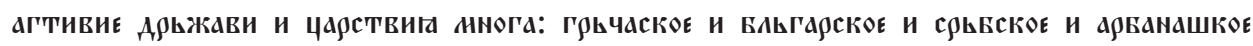
и восансков), kierujących do Boga błagalną modlitwę, aby wzniecił On ,,iskrę pobożności”, która obróci w popiół i spali „,izmaelickie carstwo”, w celu przywróce-

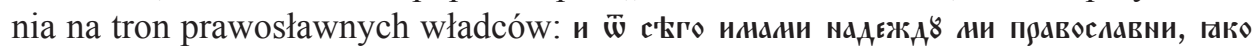
ПодоволићАь наказани нашєГО саГ

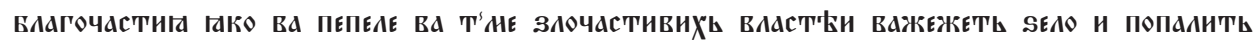

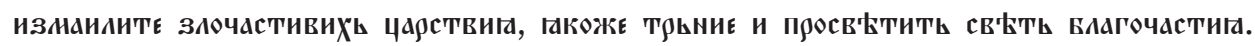
И паки вазтавитьь БАагочастивив цари пјавославига 42 .

W okresie osmańskim wśród prawosławnych na Bałkanach szczególnym powodzeniem zaczął cieszyć się znany z bizantyńsko-słowiańskiej literatury prorockiej i apokaliptycznej wspomniany już topos cesarza „końca czasów”43, z którym pier-

\footnotetext{
манската империя (към въпроса за руско-балканските културни връзки през XIX в.), „Studia Balcanica", 1974, 8, c. 109-117.

${ }^{39}$ S. Ćirković, Kraj veka - kraj sveta. Strepnje i i iščekivanja kod Srba u vezi sa 7000. godinom, „Jugoslovenski istorijski časopis”, 1996, god. XXIV, br. 1-2, s. 23; V. Ćorović, Eine Prophezeiung über den Untergang des türkischen Reiches aus dem XVIII Jahrhundert, „Archiv für Slavische Philologie”, 1909, 30, s. 312-313.

40 Tekst, zob. Два страдалиа, у: Ђ. Радојичић, Развојни лук старе српске књижевности, Нови Сад 1962, с. 284.

${ }^{41}$ Atanasije Daskal Srbin, Opustošenja srpske zemlje, u: Antologija stare srpske književnosti (XI-XVIII veka), iz. i prev. Đ. Radojičić, Beograd 1960, s. 289.

42 Р. Срећковић, Зборник митрополита Михаила, „Споменик Српске краљевске академије”, 1892, књ. 15, c. 21.

${ }^{43}$ P. Alexander, The Medieval Legend of the Last Roman Emperor and its Messianic Origin, ,Journal of the Warburg and Courtauld Institutes", 1978, 41, s. 1-15.
} 
wotnie w Objawieniu Pseudo-Metodego powiązane były trzy motywy: pokonanie Izmaelitów, zainicjowanie okresu pokoju i dobrobytu przed końcem świata oraz złożenie diademu na Golgocie po objawieniu się Antychrysta. Z czasem jednak motywy te zaczęły ulegać repartycji, fragmentacji i dyspersji ${ }^{44}$. Utożsamiający „ostatniego cesarza" z bizantyńskim basileusem Pseudo-Metody twierdził, iż po swym przebudzeniu czy zmartwychwstaniu (uważany był przez lud za martwego) wyruszy przeciwko Izmaelitom $\mathrm{w}$ wielkim gniewie $\mathrm{i}$ ich rozgromi ${ }^{45}$. W nowym kontekście historyczno-politycznym mityczny władca-wojownik stał się nośnikiem idei antyislamskich i antytureckich. O mesjańskim wyzwolicielu ujarzmionych chrześcijan dowiadujemy się m.in. z utworu epistolarno-legendarnego zachowanego w XVI-wiecznym kodeksie o treści mieszanej (Biblioteka Rumuńskiej Akademii Nauk w Bukareszcie, nr 494). Autor ,posłania” wspomina o najazdach Turków osmańskich (зАй и воүй шн危 ноүжїи исндилти $)^{46}$, dając jednak pewną nadzieję na przyszłe wyzwolenie prawosławnych chrześcijan. Przynieść ma ją mityczny wielmoża (

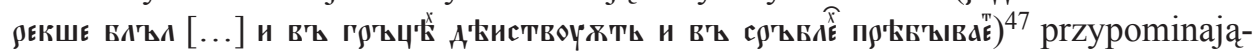
cy postać cesarza „końca czasów”48, który miał być pogromcą Izmaelitów. W utworze uwidacznia się koncepcja jedności prawosławnych Greków, Serbów i Bułgarów, połączonych zarówno figurą mesjańskiego wyzwoliciela, jak i wspólnym, tragicznym losem. Zniewoleni chrześcijanie wierząc w przyszły triumf przenosili cechy legendarnego wyzwoliciela na różne postaci historyczne, które miały zainicjować ,złoty wiek" "99, co stymulowało proces rozwoju ducha odnowy narodowej. Pod koniec XVI w. oczekiwano wielkiego powrotu św. Sawy (z czym być może związane były wspomniane wyżej ,proroctwa św. Sawy”), co niewątpliwie przyczyniło się do powstania ruchu wyzwoleńczego w kręgu serbskiego patriarchy Jovana Kantula i do wybuchu powstania w Banacie w 1594 r., podczas którego kult pierwszego serbskiego arcybiskupa odgrywał kluczową rolę ${ }^{50}$. Już wcześniej cechy legendarnego wyzwoliciela przeniesiono (1526/1527 r.) na tajemniczą postać Jovana Nenada (w niektórych dawnych proroctwach cesarz „,końca czasów” nosi imię Michał lub właśnie

44 A. Kraft, The Last Roman Emperor Topos in the Byzantine Apocalyptic Tradition, „Byzantion”, 2012, t. LXXXII, s. 213-257.

45 Слово Мефодия Патарского..., с. 19.

46 Tekst, zob. А. Милтенова, Неизвестно историко-апокалиптично съчинение за турското нашествие в препис от XVI век (Археографски и текстологични бележки), в: Византия - Балканите - Европа. Изследвания в чест на проф. В. Тъпкова-Заимова, ред. В. Гюзелев, София 2006, с. 578.

47 Ibidem.

48 Zob. P. Alexander, op. cit., p. 151-184.

49 Т. Стојановић, Структурне основе миленаризма код Јужних Словена у XVII и ХVIII веку, прев. 3. Хаџи Видојковић, „Зборник Матице српске за друштвене науке”, 2006, бр. 120, с. 21-34; T. Stojanović, Balkanski svetovi: prva i poslednja Evropa, prev. I. Đorđević, Beograd 1997, s. $204-206$.

${ }^{50}$ Informacja o sztandarze powstańczym z podobizną św. Sawy jest późna, dlatego nie może być uznana za wiarygodną. Pochodzi ona z XVII-wiecznego (wyd. Rzym 1631 r.) powstałego w kontekście kontrreformacyjnym żywota św. Sawy pióra katolickiego duchownego Ivana Tomka Mrnavicia z Šibenika, Р. Самарџић, Р. Веселиновић, Т. Поповић, Историја српског народа, књ. 3, т. 1, Београд 1994, c. 229 . 
Jan - Jovan), nazywanego „czarnym człowiekiem”, który ogłosił się carem „od Boga posłanym", zapowiadając wykorzenienie islamu i prorokując państwu osmańskiemu rychły upadek ${ }^{51}$. O „czarnym” wyzwolicielu ${ }^{52}$ (,Јавиће се један црни човјек...”) wspominał w swym proroctwie z końca XVII lub pierwszej połowy XVIII w. starzec Stanj z czarnogórskiego plemienia Vasojević. Mityczny wyzwoliciel, nazywany „carem w opankach”, w przepowiedni nosi znamiona mesjańsko-chrystologiczne, bowiem przybędzie niczym zmartwychwstały triumfator, pokona Turków („Турци ћe се све више и више губити с лица земље”) i wyzwoli chrześcijańskich Serbów, inicjując okres „złotego wieku” („Они које ослободе, живеће лијепо...”; ponadto woła: „Благо Србима који то дочекају!” ${ }^{53}$. W proroctwie tym zmodyfikowano topos władcy „końca czasów”, który już wcześniej zaczął przekształcać się w sfolkloryzowany mit o ludowym wyzwolicielu i pogromcy Turków, co widać doskonale na przykładzie jednej z najpopularniejszych postaci południowosłowiańskiego folkloru - królewicza Marko. Według legend Marko nie umarł, lecz ukrył się w tajemnej pieczarze lub na jakiejś wyspie czekając, aż wybije odpowiednia godzina wielkiego odrodzenia chrześcijan. Wówczas noszący cechy mesjańskiego oraz apokaliptycznego wyzwoliciela Marko rzekomo powstanie, wystapi przeciwko Turkom oraz przepędzi ich, inicjując okres szczęścia i rozkwitu ${ }^{54}$. Przypomina to opartą na proroctwach Leona Mędrca legendę o nieśmiertelnym, przemienionym w marmur cesarzu (utożsamianym z Konstantynem XI Paleologiem), który śpi ukryty w podziemnej piwnicy pod Złotą Bramą w Konstantynopolu (pieczarę, w której miał przebywać ukryty Marko lokowano niekiedy w pobliżu jego twierdzy w Prilepie ${ }^{55}$ ), czekając na dzień, kiedy przebudzony przez anioła przepędzi Izmaelitów ${ }^{56}$.

Aktualizowane przez cały okres tureckiego panowania proroctwa utwierdzały podbite ludy w przekonaniu o ich moralnej wyższości oraz przyszłym zwycięstwie, dlatego mogły być one pośrednimi katalizatorami bałkańskich buntów i powstan ${ }^{57}$. Wyraźne zmiany w świadomości prawosławnych chrześcijan nastapiły w XVIII w. Wcześniej inwazję Turków i domiancję osmańską postrzegano w przyczynowo-skutkowym układzie religijnych odniesień zgodnie z eschatologiczną wizją dziejów. Wierzono, że skoro jest kara, musiało być przewinienie, stąd powtarzający się topos „kary za grzechy”. Pokorni chrześcijanie zatem zgodnie z „logiką” dziejów muszą cierpieć, aby dostapić zbawienia: „przez wiele ucisków trzeba nam przejść, aby

${ }^{51}$ Zob. S. Ćirković, op. cit., s. 22-23; Д. Динић-Кнежевић, Прилог проучавању покрета Јована Ненада, „Годишњак Филозофског факултета у Новом Саду”, 1962/1963, књ. 7, с. 21-29.

$52 \mathrm{~W}$ prorockich asocjacjach być może należy doszukiwać się też etymologii przezwiska przywódcy pierwszego powstania serbskiego (1804-1813) Karađorđa (zrost słów; tureckiego słowa kara - „czarny” i imienia Đorđe).

53 В. Чајкановић, О српском врховном богу, Београд 1941, с. 116.

54 Ibidem, c. 117; T. Stojanović, Balkanski svetovi..., s. 205.

55 T. Stojanović, Balkanski svetovi..., s. 205.

56 D. M. Nicol, Konstantyn XI - ostatni cesarz Bizancjum, przeł. M. Dąbrowska, Gdańsk 2004, s. 95-96; zob. też. C. Mango, op. cit., s. 61.

${ }^{57}$ S. Ćirković, op. cit., s. 21-24; M. Hatzopoulos, Oracular Prophecy and the Politics of Toppling Ottoman Rule in South-East Europe, „The Historical Review”, 2011, vol. 8, p. 95-116. 
wejść do królestwa Bożego" (Dz 14, 22). Należało więc pogodzić się z wyrokami Bożej Opatrzności, bowiem kluczowa okazywała się wyższość moralna, triumf niezachwianej wiary w cierpieniu na płaszczyźnie transcendentnej, a nie ziemskiej, doczesnej. Powiązane jest to z pewną formą specyficznie pojmowanej teodycei konotującej usytuowanie rekompensaty zjawisk anomicznych w przyszłości, kiedy cierpienie ma zostać wynagrodzone, a niesprawiedliwość ukarana ${ }^{58}$. W XVIII w. nastąił wzrost oświeceniowej świadomości historycznej i rozpoczął się proces krystalizacji tożsamości narodowej, dlatego zmieniła się również percepcja Imperium Osmańskiego i Turków, postrzeganych już nie jako zasłużona kara, lecz raczej jako zagrożenie dla bytu narodowego, przeszkoda na drodze postępu oraz rozwoju. Oczywiście, interpretacja eschatologiczna dziejów spełniała jeszcze pewną rolę aż do XIX w., ale już nie jako dominujący, lecz lateralny wzorzec alternatywny.

\title{
THE TURKS AND THE OTTOMAN EMPIRE IN SOUTH SLAVONIC PROPHECIES
}

\author{
PAWEL DZIADUL
}

Summary

The main aim of this work is the presentation and analysis of anti-turkish and anti-Islamic ideas found in the South Slavonic prophecies. Prophetic and apocalyptic literature developed in two connected directions in the Ottoman period among the Orthodox Slavs in the Balkans. On the one hand, old prophetic and apocalyptic material (such as the Revelation of Pseudo-Methodius, prophecies of Leo the Wise, the apocryphal Visions of Daniel) was actualized according to new historical-political circumstances. On the other hand, new anti-turkish prophecies were created in that period. However, marginal glosses, interpolations or compilations were often used in that process. Anti-turkish and anti-Islamic ideas focused mainly on the future Ottoman doom and the image of the legendary emperor who was supposed to defeat the "Ishmaelites"

58 P.L. Berger, Święty baldachim: elementy socjologicznej teorii religii, przeł. W. Kurdziel, Kraków 1997, s. 108. 